\title{
The Power of Innovativeness in Manufacturer-Retailer Relationships
}

Silke Lennerts, Prof. Dr., Assistant Professor, University of St.Gallen, Center for Customer Insight, Email: silke.lennerts@unisg.ch (Corresponding author)

Martin Eisend, Prof. Dr., Full Professor, European University Viadrina Frankfurt (Oder), Department of International Marketing, Email: : eisend@euv-frankfurt-o.de

Theo Lieven, Dr., Post Doc, University of St.Gallen, Center for Customer Insight, Email: theo.lieven@unisg.ch

Sven Molner, Dr., Post Doc, University of St.Gallen, Center for Customer Insight, Email: sven.molner@unisg.ch

Tim Oliver Brexendorf, Prof. Dr., Assistant Professor, WHU - Otto Beisheim School of Management, Henkel Center for Consumer Goods, Email: tim.brexendorf@whu.edu

Torsten Tomczak, Prof. Dr., Full Professor, University of St.Gallen, Center for Customer Insight, Email: torsten.tomczak@unisg.ch 


\section{The Power of Innovativeness in Manufacturer-Retailer Relationships}

\section{Structured Abstract:}

\section{Purpose}

Retailers often challenge manufacturers through aggressive store brand policies and severe listing constraints. This study investigates manufacturer innovativeness as a managerial lever to shift the power balance between manufacturers and retailers.

\section{Methodology/Approach}

Using data from 277 senior managers of Swiss and German consumer goods manufacturers and analysing these data with structural equation modelling, the authors test hypotheses about the impact of manufacturer innovativeness on manufacturer-retailer relationship characteristics (i.e., retailer dependency, store brand aggressiveness, and listing constraints).

\section{Findings}

The study demonstrates that manufacturer innovativeness enhances retailer dependency, which in turn positively affects overall manufacturer performance. This relationship can be explained further: by increasing retailer dependency, manufacturers suppress retailers' store brand aggressiveness and attenuate retailers' listing constraints. Store brand aggressiveness affects overall manufacturer performance through listing constraints.

\section{Research Implications}

Identifying levers such as innovativeness that assist manufacturers in fostering their power over retailers provides a new mode for understanding how manufacturers can influence the balance of power between manufacturers and retailers. The study provides support for the 
approach/inhibition theory of power on the inter-organizational level. Organizations with increased power are assumed to have approach-related tendencies and act in goal-consistent manner, whereas organizations with reduced power are assumed to develop the tendency to pursue inhibition-related actions, e.g., attending to threats. Furthermore, this study identifies channel relationship characteristics such as retailer dependency as a mediating path between manufacturer innovativeness and performance.

\section{Practical Implications}

Managers need to strengthen the firm's innovative capacity to enhance the performance of their companies. By developing the capability to develop radical innovations, manufacturers are able to enhance their performance not only directly but also indirectly by strengthening the manufacturer's position with regard to retailers. This study underscores the relevance of innovativeness for strengthening the manufacturer's position in its relationship with retailers that even avoids problems with aggressive store brands and constrained listing conditions.

\section{Originality/Value/Contribution}

This study proposes manufacturer innovativeness as a managerial lever to shift the power balance between manufacturers and retailers.

\section{Keywords:}

Manufacturer innovativeness, manufacturer-retailer relationship, retailer dependency 


\section{The Power of Innovativeness in Manufacturer-Retailer Relationships}

\section{Introduction}

Today, many retailers often challenge manufacturers (e.g. Corstjens and Corstjens 2000; Mysen et al. 2012). The power of retailers affects overall manufacturer performance for at least two reasons. First, retailers exercise their power over a manufacturer by imposing severe listing constraints (e.g. Geylani et al. 2007; Gomez and Benito 2008). Listing constraints refer to any intentionally imposed obstacle by a retailer to detain or hamper the sale of a manufacturer's products in the retailer’s outlets. This includes amongst other presentation fees, slotting, display, pay-to-stay, and failure fees (Bloom et al. 2000), advertising subsidies, and other requests for advantages, such as credit terms, delivery terms, and cases of free goods like rebate in kind (Marx and Shaffer 2004). Second, retailers exercise their power by implementing aggressive store brand policies (e.g. Ailawadi 2001; Collins and Burt 2003). Store brands allow for higher margins than manufacturer brands (Ailawadi and Harlam 2004), because they can be offered at lower prices due to lower advertising and overhead costs, which are absorbed by the retailer's total budget, while manufacturers often employ large budgets to "push" their brand (Morris 1979). This gives retailers more flexibility and space for profit. In addition, when a retailer offers similar products as a manufacturer, but under the retailer's own brand name, it is difficult for consumers to make price checks because the products do not seem to be identical. This reduces pressure on the retailer's price and might increase profits. Retailers may succeed in positioning their store brands as an equal or even better alternative to manufacturer brands (Burt 2000). Hence, both listing constraints and the introduction of store brands threat manufacturers’ profit and market share.

To deal with these challenges, manufacturers seek to re-establish their power position in relation to retailers. This study proposes that a manufacturer's innovativeness might be a key component of an effective strategy to re-establish bargaining and negotiating power in 
relation to retailers that eases dependency of manufacturers from retailers. Radically new products such as Apple's iPhone and Red Bull have substantial customer appeal and increase customer demand. Retailers can hardly afford to cast off such highly innovative products, and therefore, the manufacturers of these products are in an advantageous position. In this study, the authors examine the impact of manufacturer innovativeness on the power balance in manufacturer-retailer relationships by analysing data from manufacturers in Switzerland and Germany. The findings show that manufacturer innovativeness contributes to overall manufacturer performance by increasing retailer dependency and that the mediating effect of retailer dependency mitigates the threats of store brand aggressiveness and listing constraints. In this regard, the study contributes to the extant marketing literature in the following ways:

First, the study contributes to the discussion on channel relationships that focuses on the power balance between manufacturers and retailers (Bloom and Perry 2001). Extant research on the power balance in distribution channels investigates the power relations among channel members and the structural determinants of these relations, such as market and channel characteristics that are largely exogenous to the manufacturer (e.g. number and concentration of retailers and manufacturers) (e.g. Brown et al. 1983; Collins 2002). Beyond the prospect of strengthening a manufacturer's brand (e.g. Glynn et al. 2012), scholars provide virtually no guidance as to how a manufacturer can improve its power position towards retailers by actively influencing determinants of the manufacturer-retailer relationship. Identifying levers such as innovativeness that assist manufacturers in fostering their power over retailers provides a new mode for understanding how manufacturers can influence the balance of power between manufacturers and retailers. Such understanding can facilitate a manufacturer's ability to negotiate favourable listing conditions and attenuate the retailer's store brand aggressiveness.

Second, most of the social psychological theories on power could be situated on an intra- and inter-individual, intergroup, and ideological level (Doise 1986; Brauer and Bouhis 
2006). This study extends the social psychological literature by analyzing the effects of power on the inter-organizational level.

Third, this study advances the literature on the relevance of a firm's innovativeness. While previous research has largely provided support for the effect of innovativeness on performance-related measures (e.g. Hult et al. 2004; Sorescu and Spanjol 2008), researchers have not yet considered channel relationship characteristics as mediating variable. The gap in research is surprising given the relevance of channel relationships for manufacturer performance (Ailawadi 2001). This study identifies channel relationship characteristics as a mediator between manufacturer innovativeness and overall manufacturer performance. In so doing, we provide a means of better understanding how innovativeness creates value for manufacturers.

The manuscript's structure is as follows: The manuscript first establishes the theoretical background and a conceptual model. The authors then derive hypotheses for the model, and they describe the research methodology of the study and present the results. Next, the authors discuss the findings in light of the proposed theory and hypotheses. They outline the theoretical contributions of the study and the managerial implications. The manuscript concludes with a discussion of research limitations and directions for further research.

\section{Theoretical Background and Conceptual Model}

This research primarily roots in the behavioral-based concept of power in distribution channels (Brown et al. 1983; Gaski and Nevin 1985). Power in a distribution channel refers to a channel member's control over and ability to alter the behavior of another channel member, so that the other channel member takes actions that would not have been taken otherwise (ElAnsary and Stern 1972). Scholarly conceptualizations of power in channels of distribution primarily refer to Emerson's (1962) concept of dependency. 
Emerson's (1962) concept of dependency, in tradition of Thibaut and Kelley (1959) and Kelley and Thibaut (1978), argues that power resides implicitly in a channel member's dependency upon another channel member. A retailer's dependency is directly proportional to its investment in goals mediated by the manufacturer (e.g. retailer's revenues) and inversely proportional to the availability of these goals to the retailer outside the particular retailermanufacturer relationship. Put differently, the dependency of a retailer upon a manufacturer is reflected in how essential the manufacturer's goods are in fulfilling a retailer's goals and in the difficulty the retailer perceives in switching to alternative sources of supply (Brown et al. 1983).

This study applies the terminology of the distribution channel literature (Frazier 1999) and refers to dependence structures between channel members to describe and discuss the distribution of power between channel members.

Retailers exercise their power primarily by imposing severe listing constraints (Geylani et al. 2007) and pursuing aggressive store brand policies (Ailawadi 2001), both of which have significant implications for overall manufacturer performance. Because retailers' have the ability to deny manufacturers' access to the shelves, the threat of delisting and the retailers' listing fees critically affect a manufacturer's sales volumes. Store brands can become threatening competitors to manufacturer products, inasmuch as they might gain market shares at the expense of the manufacturer's brands (Narasimhan and Wilcox 1998). They also increase price sensitivity in a product category and thus lower revenues for manufacturers (Chintagunta et al. 2002).

On the basis of the aforementioned considerations, this study develops and tests a model that analyses the effects of manufacturer innovativeness on retailer dependency. Retailer dependency in turn affects retailers' store brand aggressiveness, listing constraints and overall performance. Figure 1 shows the conceptual model that guides the present research. 


\section{Hypotheses}

\section{Manufacturer Innovativeness and Overall Performance}

Manufacturer innovativeness refers to a manufacturer's "tendency to engage in and support new ideas, novelty, experimentation, and creative processes that may result in new products, services, or technological processes” (Lumpkin and Dess 1996). This study focuses on radical innovation, which aligns with anecdotal evidence of retail practitioners who complain about the glut of incrementally new products such as me-too products and demand more creativity of manufacturers (Udell and Pettijohn 1991). Radical product innovations involve fundamental changes in technology for a company and are new to the company and/or the industry. They offer substantial new benefits for customers. In contrast, incremental product innovations are refinements and line extensions that are new for the company, but they are not new for the market (Chandy and Tellis 1998). Thus, manufacturer innovativeness is conceptualized as investment in radically new product innovations and the amount of radically new product introductions compared to that of competitors (Covin and Slevin 1989; Garcia-Morales et al. 2006). The literature (Hult et al. 2004) largely supports a direct relationship between manufacturer innovativeness and overall performance. This relationship provides the central path for the model of this study. The following argument will determine this relationship by identifying several mediating effects.

\section{Manufacturer Innovativeness and Manufacturer-Retailer Relationship Characteristics}

According to Emerson's concept of dependency, the higher the contribution of manufacturer's products to retailer performance, the greater the power base of a manufacturer will be with regard to the retailer, which, in turn, increases the retailer's dependency on the manufacturer. Radically new products can have a significant impact on market success and consequently on retailer performance, because these products have strong customer appeal, 
increase customer demand, and open new product domains (Danneels 2002; He and Wong 2004). Manufacturers that introduce radically new products achieve a leading position in a market as a first-mover (Urban et al. 1986) and are thereby able to achieve high percentage margins. Such radically new products contribute to retailer performance by improving sales volumes, sales values, and profit margins (Sriram and Kadiyali 2009) while being difficult for retailers to substitute. Therefore, a manufacturer's supply of radically new products can increase retailer dependency.

The dependency between manufacturer and retailer is mutual or relative. Relative dependency means that both the manufacturer and the retailer depend mutually on each other, but one may depend relatively more on the other (Anderson and Narus 1990), which refers to an asymmetrical power relationship (Blois 2010). Following resource dependence theory (Pfeffer and Salancik 1978, for an overview cf. Hillman et al. 2009) mutual dependencies can be numerous on both sides. In new product development (NPD) the relative dependency has an even greater positive effect on manufacturer-distributor cooperation than trust, commitment, shared value, or communication (Song and Zhao 2004).

The relative or mutual dependency suggest that manufacturer innovation and retailer dependency are correlated, but do not necessarily follow a causal relationship. Innovation implies a power-dependence relation where "power resides implicitly in the other's dependency” (Emerson 1962). While the overall dependency may be mutual since power always involves at least two parties (Huxham and Beech 2009), it is the manufacturer who has the resources to create innovative products. The degree of retailer dependency is related to the degree of innovativeness and competition among manufacturers. It is in fact the radicalness of the innovation (Hernandez-Espallardo and Molina-Castillo 2012) that increases manufacturer's power. The extant literature identifies innovation to be a successful strategy to compete with retailers' store brands (Verhoef et al. 2000), while store brands flourish in 
environments with low innovation (Kumar and Steenkamp 2007b). Thus, we assume a causal effect of manufacturer power over the retailer, whose dependency will increase:

H1: The more innovative manufacturer's products the higher retailer's dependency. Retailers are likely to exercise their power by imposing severe listing constraints and pursuing aggressive store brand policies that cause conflict in the manufacturer-retailer relationship (Gaski 1984). By increasing retailer dependency and thereby reducing the power of retailers, manufacturers can create conditions by which retailers are not only less capable of exercising power but also able to avoid conflict-laden actions, establish positive interactions, and maintain a stable relationship with retailers. Social power studies provide evidence that individuals in a low power positions are motivated to establish smooth and pleasant interactions with individuals in high power positions (Copeland 1994).

H2: The higher the retailer dependency the lower the store brand aggressiveness. The same holds for listing constraints which prevent manufacturers from being listed in the shelves of the retailer or where listings are granted only against a lump sum. Bloom et al. (2000) found a direct association between retailer market power and slotting fees which is one kind of listing constraint: higher market power reduces slotting fees. Thus, the more the manufacturer can restrict retailers’ power the less probable are listing constraints.

H3: The higher the retailer dependency the fewer listing constraints are imposed. Store brands and listing constraints are interrelated concepts. Retailers make trade-offs between manufacturer and store brand products in considering which assortment of products to offer. Retailers who invest heavily in store brands will favour their own products when making assortment considerations and increase listing constraints for manufacturer products to promote store brand products, for example, by improving the shelf position of their own brands at the expense of a manufacturer's brands (Steenkamp and Dekimpe 1997; Kumar and Steenkamp 2007a). Store brand aggressiveness therefore increases listing constraints for manufacturers. 
H4: The higher the store brand aggressiveness the more listing constraints are imposed.

Retailer dependency on a manufacturer leads to a less aggressive retailer store brand policy with regard to this manufacturer; at the same time, store brand aggressiveness increases listing constraints. This relationship provides an alternative path and an additional explanation to the direct relationship between retailer dependency and listing constraints as stated in hypothesis 3. When retailers exert power, they can ask lump sums in order to accept listings with the purpose to increase revenues by these extra fees. In these cases, the direct effect of retailers' power (i.e, non-dependency, Emerson 1962) increases the listing constraints directly. However, when alternative store brands are considered, more listing constraints are imposed because of limited shelf space (Gomez and Rubio 2008). In other words, the negative relationship between retailer dependency and listing constraints can be explained by the bargaining position (direct path as stated in hypothesis 3) and by the fact that retailer dependency determines store brand aggressiveness (as stated in hypothesis 2), which in turn affects listing constraints imposed by retailers (as stated in hypothesis 4) (Suarez 2005; Amrouche and Zaccour 2006). The resulting mediating path is described in the following hypothesis:

H5: Store brand aggressiveness mediates the relationship between retailer dependency and listing constraints, such that retailer dependency reduces store brand aggressiveness that increases listing constraints.

Manufacturer-Retailer Relationship Characteristics and Overall Manufacturer Performance As a channel member becomes stronger in the market and its market power increases, its relative economic return increases as well (Ailawadi et al. 1995). For instance, the largest U.S. retailer Wal-Mart has squeezed suppliers financially (Bloom and Perry 2001). Ailawadi, Borin, and Farris (1995) found evidence of a relationship between increased power and profit. 
Further, increasing retailer dependency will positively affect overall manufacturer performance. In highly competitive markets like the grocery channel where end users possess most of the power, those gains could have been gone in the only direction of the consumers (Messinger and Narasimhan 1995). We assume that retailer dependency directly affects overall manufacturer performance, because such dependency improves a manufacturer's relationship with customers and gives it an advantage over competitors.

H6: The higher the retailer dependency the better manufacturer's performance. The positive impact of manufacturer innovativeness on retailer dependency is an indication of the direct and well-established relationship between manufacturer innovativeness and performance. Manufacturer innovativeness contributes to overall manufacturer performance by affecting retailer dependency. According to the social psychology theory increased power of A over B (i.e. increased dependency of B, Emerson 1962) is a catalyst to engage in actions and to act in a goal-consistent manner (Galinsky et al. 2003). Moreover, people who exert power are more concerned with learning about their partners (Copeland 1994). Consequently, people with increased power will archive a larger share of the pie in negotiations (Giebels et al. 2000; van Kleef et al. 2006). Referring to this theory, retailer dependency can be seen as a mechanism that transforms manufacturer innovativeness into overall success of the manufacturer by learning about the retailers who distribute the innovations, reducing deliberation of the manufacturer, and pursuing innovative actions in a goal-consistent manner. Furthermore, retailer dependency ensures stable future revenue inflows because dependent retailers serve as reliable and readily accessible launching platforms for future products (van Everdingen et al. 2011).

The mediating effect is partial as innovativeness has a direct effect on performance that can be explained by other characteristics beyond retailer dependency such as consumers' needs for new and innovative products. 
H7: Retailer dependency mediates the effect of manufacturer innovativeness on overall manufacturer performance, such that manufacturer innovativeness increases retailer dependency, which improves overall manufacturer performance.

Retailers exercise their power by imposing severe listing constraints in an effort to extract a large fraction of channel profits, which in turn affects overall manufacturer performance. Listing constraints determine how overall channel margins are allocated between the manufacturer and the retailer. If retailers with strong bargaining power impose stricter listing conditions, the retailers' share of channel profits increases while the manufacturer's share decreases, which determines overall manufacturer performance (Lan et al. 2007). Listing constraints relate not only to prices but also to the period in which retailers list a product. The less time retailers give, the more likely the diffusion of products is inhibited and the less likely manufacturers are able to amortize investments in product development and market introduction. In sum, listing constraints have a negative impact on overall manufacturer performance.

H8: Listing constraints reduce overall manufacturer performance.

The relationship between listing constraints and overall manufacturer performance provides another explanation for the direct relationship between retailer dependency and overall manufacturer performance. Listing constraints depend on retailer dependency as stated in hypothesis 3, which in turn affect overall manufacturer performance. That is, the positive relationship between retailer dependency and overall manufacturer performance caused by the favourable position of a manufacturer towards customers and over competitors can be further explained by fewer listing constraints imposed by retailers on highly innovative manufacturers and their products. Power studies in social psychology assume that individuals who experienced less power (i.e. dependency, Emerson 1962) have a tendency to inhibit, e.g., attending to threats and showing more smooth behavior (Keltner et al. 2003). Thus, this effect of inhibition and avoidance can be seen as a catalyst of the positive relationship between 
retailer dependency and manufacturer performance. With increasing retailer dependency, a manufacturer may benefit from less listing fees and from favourable shelf-space allocation decisions by retailers, which leads to increased shelf-space availability. Shelf-space availability and prominence influences customers' buying decisions in a favourable way, yielding better performance outcomes (Martín-Herrán et al. 2006). If shelf-space allocation decisions occur at the expense of competitors' shelf-space (Ailawadi et al. 1995), a manufacturer's competitive situation improves, which further positively influences customers' buying decisions and overall manufacturer performance.

H9: Listing constraints mediate the relationship between retailer dependency and overall manufacturer performance, such that retailer dependency reduces listing constraints that reduce overall manufacturer performance.

Retailers also exercise their power through store brand aggressiveness in an effort to extract a large fraction of channel profits, because store brands affect the way profits are split in the distribution channel (Draganska et al. 2010). Store brands compete with manufacturer products, leading to a battle over market share and to increased price sensitivity in a product category (Narasimhan and Wilcox 1998; Chintagunta et al. 2002). Therefore, an aggressive store brand policy negatively affects overall manufacturer performance, which can be explained by lower prices and margins of manufacturer brands due to competition by store brands (Krishnan and Soni 1997).

H 10: Store brand aggressiveness reduces overall manufacturer performance. The strength of the direct causal effect of store brand aggressiveness on manufacturer performance is questionable, because listing constraints provide an additional explanation as mediator of this relationship. The store brand will capture revenues from the manufacturer brand, and thus, reduce manufacturer revenue and performance (Chung 2008). Severe listing constraints may act as a catalyst of this relationship by providing more shelf-space for the store brands at the expense of the manufacturer's innovations and making favourable shelf- 
space allocation decisions with regards to the store brands. This, in turn, reduces the manufacturer’s revenues and performance (Scott Morton and Zettelmeyer 2004).

H 11: Listing constraints mediate the relationship between store brand aggressiveness and overall manufacturer performance, such that store brand aggressiveness increases listing constraints that reduce overall manufacturer performance.

\section{Method}

\section{Sample and Data Collection}

We focus on manufacturers in the consumer goods industry in Germany and Switzerland and their relationship with retailers. Retailers in both countries have achieved considerable market power (Weber and Anders 2007); in 2010, the TOP 5 retailers showed a market share of 71\% in Switzerland and 61\% in Germany. Further, Switzerland and Germany belong to the TOP 3 countries concerning the market shares of store brands in the fast moving consumer goods market. The market share of store brands accounts for $46 \%$ in Switzerland and for $34 \%$ in Germany (MetroGroup 2012).

This study uses a sample from a commercial mailing list and from published directories of the top manufacturing companies operating in the consumer goods industry. Experts were initially chosen and interviewed to identify knowledgeable informants in the field, to validate the scales, to discuss and verify the conceptual model, and to mitigate the problems of singleresponse bias. All postulated relationships seemed plausible to the experts. The interviewed experts described the power of the retailers as a barrier they have to deal with. Listing constraints and store brand aggressiveness are major threats manufacturers are confronted with regarding radical innovations.

After interviewing CEOs, marketing managers, sales managers, and experts from brand manufacturer associations, the authors selected CEOs and senior marketing managers as key informants, because they are most knowledgeable about their company's innovativeness, the established business conditions and relationship characteristics of retailers, and the company's 
overall performance. Because many senior managers from retailers take over jobs in the consumer goods industry and vice versa, a high permeability of job change exists at the senior management level in the retail and consumer goods industry exists. Day and Malcolm (2012) underline this argument. They highlight that "CMOs ([Chief Marketing Officers]) (...) come from a wide experience and educational base.” (p. 40). Thus, CEOs and senior marketing managers are considered to be reliable informants in the context of this study. Each company in the sample was contacted by telephone in order to locate CEOs or marketing directors at the strategic business unit (SBU) level and to identify his or her name and e-mail address.

In all, 1,100 CEOs and senior marketing managers received e-mails that provided a link to the online questionnaire. To encourage participation, we offered summary reports of the results to all respondents. After an initial and two follow-up mailings, 277 completed questionnaires were returned, which yielded a participation rate of 25\%. The results show no differences between Swiss respondents (145) and German respondents (123) across all variables in this study. Of the key informants responding to the survey, 92\% held positions of CEO or director of marketing within their respective companies. The data reveal no evidence of informant bias due to respondents with different backgrounds (CEOs vs. directors of marketing vs. senior executives in market research, purchasing, or business development).

To examine non-response bias, we checked for differences between the first wave respondents (after initial mailing) and the second and third wave respondents (after second and third mailing) (Armstrong and Overton 1977). We found no significant differences between early and late respondents on the measures used in the study.

The sample comprises brand manufacturers from different sectors: food and beverages (35.7\%); textiles, clothes, and footwear (15.5\%); cleaning, hygiene, and cosmetics (10.1\%); office supplies, computer, and telecommunications (6.9\%); do-it-yourself and building material (5.8\%); leisure, sports, and activities (6.5\%); electric appliances and lighting (5.1\%); consumer electronics, audio media, and audio-visual media (3.2\%); household goods, 
glassware, and dishware (2.9\%); furnishings (2.5\%); personal goods and services (1.8\%); and others (4.0\%). This distribution is consistent with the structure of private demand in the different consumer goods areas in Germany and Switzerland (MetroGroup 2012). Concerning company size, 32.1\% of the companies had less than 50 employees, 33.2\% had between 50 and 249 employees, and 34.7\% of the companies had 250 or more employees.

\section{Measures}

This study uses measurement items derived and adapted from validated scales. The scales of store brand aggressiveness and listing constraints are developed on the basis of a literature review and in-depth interviews with six practitioners with various tenures in the consumer goods industry. The authors have pre-tested the resultant questionnaire and have refined the questions on the basis of comments from practitioners. The study employs a five-point Likert scale for all measures. Table 1 contains a complete list of measures and items.

\section{Table 1 here}

Manufacturer innovativeness. Two commonly used indicators measure manufacturer innovativeness (Spanos and Prastacos 2004). This scale captures the development of expenses for research and development of radical new products within the last years and the number of radically new products compared to those of competitors.

Retailer dependency. For measuring the dependency of retailers upon the manufacturer, the study uses three items from Collins (2002). Collins (2002) conducted a study of 55 Irish food manufacturers regarding the dependency of their retailers. According to Emerson’s concept of dependency, the power of a manufacturer over a retailer is equivalent to the retailer's dependency upon the manufacturer. Because dependency is the other side of power, manufacturers should have the ability to answer the above mentioned questions properly.

Store brand aggressiveness. Store brand aggressiveness includes the manufacturer's assessment of the extent how quickly retailers develop store brands and whether this 
development is an increasing threat for the distribution of their own products. In particular, the scale refers to the degree to which retailers develop store brand alternatives to the manufacturer's products and to what degree me-too products follow the introduction of promising product innovations.

Listing constraints. The measure of listing constraints employs three items focusing on the perception of the manufacturer regarding the increase of listing fees within the last years, the increased shortness of time given by the retailer for keeping the manufacturer's product on the shelves, and the expectation of the retailers concerning speed-to-market of new product introductions.

Overall manufacturer performance. A set of scale items drawn from DeSarbo et al. (2005) and Hooley et al. (2005) serves as a measure of overall performance. The measure employs the marketing managers' evaluation of the achievement of the overall profit goal and the return on investment goal as well as of the achievement of these goals compared to the main competitors.

Control variables. Dependency structures are related to power asymmetries that might also be explained by the mere size of the manufacturer or retailer, market characteristics (e.g. uncertainty, turbulence) or the longevity and maturity of relationships. The size of the manufacturer shows considerable variance in the dataset, while the size of the retailers is subject to less variation because of only few retailers with high market power. In order to control for variations in power asymmetry due to company size, this research includes manufacturer size as measured by the natural logarithm of the number of full time employees as a control variable. The study defines a series of dummy variables to control for industry sectors that typically differ in terms of the degree of innovativeness of new products, the degree of competitiveness, and their influence on the suggested relationships. The industry dummies are 1. food and beverages; 2. textiles, clothes, and footwear; 3. cleaning, hygiene, and cosmetics; 4. office supplies, computer, and telecommunications; 5. do-it-yourself and 
building material; 6. leisure, sports, and activities; 7. electric appliances and lighting, 8. consumer electronics, audio media, and audio-visual media; 9. household goods, glassware, and dishware; 10. furnishings; 11. personal goods and services; and 12. others. Items from scales by Jaworski and Kohli (1993) are used to control for industry uncertainty and turbulence. To control for the longevity and maturity of the relationships between manufacturer and their retailers, we use manufacturer's non-economic satisfaction with their retailers, assuming that longevity and maturity of a relationship are strongly related to noneconomic satisfaction. We adapt two items from Yu and Psyarchik’s (2002) scale for retailers' non-economic satisfaction with their manufacturers and add an item considering the retailers as a good partner for collaboration.

To validate the measurements, we conduct exploratory factor analyses. Each of the 21 items loads significantly on its intended factor. Cronbach's alpha coefficients for the constructs range from .65 to .93, indicating adequate internal consistency (Churchill 1979). The study assesses construct validity of all items pertaining to each construct through a confirmatory factor analysis. The composite reliability coefficients range from .65 to .93 for each construct, verifying adequate internal consistency of the measures (Bagozzi and Yi 1988). A confirmatory factor analysis on all items yields a model that fits the data well $(\chi 2=335.23, \chi 2 / \mathrm{df}=1.54, \mathrm{CFI}=.95, \mathrm{TLI}=.94, \mathrm{RMSEA}=.044)$. All factor loadings are statistically significant $(\mathrm{p}<.001)$. These results indicate convergent validity of the measurement scales. Table 2 provides the correlation matrix of the constructs. In all cases, the average variance extracted for each construct is greater than its squared correlation with other constructs, exhibiting discriminant validity (Fornell and Larcker 1981) Although the average variance extracted is below .5 for some constructs, we keep all of the constructs because Cronbach's alpha and the composite reliability is acceptable and the requirement of discriminant validity was met. 
Because the data are based on self-reports, procedures to account for problems of common method variance are in place. First, as recommended by Feldman and Lynch (1988), the model's constructs do not appear in the hypothesized order in the questionnaire, and pretests with the target population helped us to counter "self-generated validity".

Second, following Podsakoff and Organ (1986), we employ Harman's one-factor. After entering all items into a single factor analysis, the analysis extracts seven factors with Eigenvalues greater than one, accounting for $68 \%$ of the variance. Thus, no single factor emerges, and no single factor accounts for most of the total variance in the items.

Third, we use a CFA extension of the correlational marker technique (Lindell and Whitney 2001; Williams et al. 2003) since Harman’s test is only a necessary condition to preclude common method bias. More recent techniques implement a so-called marker (age, place of citizenship etc.) that is assumed to be unrelated to all other variables. If this marker loads high on all other variables, the risk of common method bias is high; otherwise, common method bias is negligible. Satisfaction with the shop opening hours in the country serves as a marker variable in this study, which is theoretically irrelevant to the focal constructs of the model. The marker variable applies one item (five-point Likert scale with 1=strongly disagree and 5=strongly agree). In order to test for the presence of common method variance, the authors compare the change in fit between a model in which the paths from the marker variable to the manifest indicators of the substantive variables are constrained to zero to a model in which they are estimated freely. The change-in-fit-statistics $\left(\Delta \chi^{2}=20.01, \Delta\right.$ d.f. $=19$, $\mathrm{p}>0.10$ ) indicate that common method bias is not significant. These results indicate that the data do not suffer from common method variance.

\section{Analysis and Results}


The analysis of the hypotheses uses Mplus V.5. The overall fit measures of the structural model indicate adequate fit of the model to the data $(\chi 2=351.22, \chi 2 / \mathrm{df}=1.60$, CFI $=.95$, TLI $=.93, \mathrm{RMSEA}=.046)$. Figure 2 provides the parameter estimates of the direct effects.

\section{Figure 2 here}

Manufacturer innovativeness has a positive impact on overall manufacturer performance $(\beta=.15, t=2.05)$. Manufacturer innovativeness enhances retailer dependency $(\beta$ $=.19, \mathrm{t}=2.19$ ), supporting hypothesis 1 . Retailer dependency has a significant negative impact on store brand aggressiveness $(\beta=-.15, \mathrm{t}=-2.06)$, supporting hypothesis 2 . The effect from retailer dependency to listing constraints is not significant $(\beta=-.12, t=-1.53)$, rejecting hypothesis 3. The results provide support for a positive effect of store brand aggressiveness on listing constraints $(\beta=.29, \mathrm{t}=4.08)$, supporting hypothesis 4 . Retailer dependency is significantly related to overall manufacturer performance $(\beta=.29, \mathrm{t}=3.62)$, as suggested by hypothesis 6 . Whereas the data reveal that listing constraints negatively affect overall manufacturer performance $(\beta=-.17, t=-1.97)$, as suggested by hypothesis 8 , we find no support for the expected negative effect of store brand aggressiveness on overall manufacturer performance $(\beta=.05, \mathrm{t}=-.75)$. Thus, hypothesis 10 is not supported.

In order to test for mediation effects, the study applies Sobel z-Tests, following the recommendations made by Iacobucci et al. (2007). As predicted in hypothesis 5, the results confirm a fully suppressor effect of store brand aggressiveness on the relationship between retailer dependency and listing constraints $(\mathrm{z}=-1.74 ; \mathrm{p}<.10)$, such that retailer dependency attenuates store brand aggressiveness that enhances listing constraints. We find partial mediation of retailer dependency on the relationship between manufacturer innovativeness and overall manufacturer performance $(\mathrm{z}=1.81 ; \mathrm{p}<.10)$, supporting hypothesis 7 . The mediation through retailer dependency explains $25 \%$ of the variance in overall manufacturer performance. The findings do not support hypothesis 9, which predicts a mediation effect of listing constraints on the relationship between retailer dependency and overall manufacturer 
performance, since the effect of retailer dependency on listing constraints is not significant. Listing constraints fully mediate the relationship between store brand aggressiveness and overall manufacturer performance $(\mathrm{z}=-1.82 ; \mathrm{p}<.10)$, such that store brand aggressiveness increases listing constraints that have a negative impact on overall manufacturer performance. The finding supports hypothesis 11.

The inclusion of the control variables in the model provides robust results for the main relationships. Figure 2 shows major effects of the control variables.

Table 3 depicts an overview of the findings of our analysis. The analysis shows that manufacturer innovativeness enhances retailer dependency. Furthermore, our findings indicate that retailer dependency is the main mediating factor that contributes to overall manufacturer performance. Store brand aggressiveness and listing constraints further demonstrate the relationship between retailer dependency and overall manufacturer performance. Retailer dependency does not directly affect listing constraints; however, retailer dependency mitigates store brand aggressiveness, which, in turn, leads to an attenuation of listing constraints. Furthermore, store brand aggressiveness affects overall manufacturer performance through listing constraints.

\section{Table 3 here}

\section{Discussion}

\section{Theoretical Contributions}

The advantageous power position of retailers in many industries challenges manufacturers to find ways to shift the power balance between retailers and manufacturers (Ailawadi et al. 2010). With innovativeness, we propose a concept and a managerial lever that contributes to related research in several ways.

First, the results show that manufacturer innovativeness affects the power balance in distribution channels (Ailawadi et al. 2010). Most studies focus on the structural determinants of channel members' power position, which are exogenous from a managerial point of view 
(e.g. Davies et al. 1985; Grant 1987; Dobson and Waterson 1999; Collins 2002) and can be hardly influenced by managerial action. Innovativeness is an endogenous variable and a managerial lever by which a manufacturer can proactively strengthen the power position. Further, retailer dependency reduces store brand aggressiveness, which indirectly affects overall manufacturer performance through mitigating listing constraints. Research on channel relationships identifies listing constraints and store brand activities as drivers of channel profit distribution among channel partners that favour retailers over manufacturers and drive retailer margins.

Second, we analyze power and dependency respectively on the inter-organizational level. Our study indicates that retailer dependency and thus manufacturer power can be seen as a mechanism which transforms manufacturer innovativeness into overall success by reducing manufacturer's deliberation and pursuing innovative actions in a goal-consistent manner. Furthermore, the study shows that the more reduced power and the more dependent retailers are respectively, the more they show a tendency to inhibit, e.g., less aggressive store brand policies. These findings are in line with the approach/inhibition theory of power (Keltner et al. 2003). According to this theory people with increased power should be associated with increased rewards and approach-related tendencies, whereas individuals with reduced power are assumed to develop the tendency to pursue inhibition-related actions, e.g., attending to threats. The results of our study provide support for this theory on the interorganizational level. Most of the social psychological theories on power could be situated on an intra- and inter-individual, intergroup, and ideological level (Doise 1986; Brauer and Bouhis 2006). Thus, our study extends the social psychological literature by analyzing the effects of power on the inter-organizational level.

Third, this study advances the extant literature on innovativeness. Practitioners and scholars believe that innovativeness is crucial for gaining competitive advantage (Hurley und Hult 1998). Though the extant research scrutinizes innovativeness from different angles (e.g. 
Calantone et al. 2002; Hult et al. 2004), the effects of innovativeness on relationships with key market players remain largely unexplored. On the basis of the results of their 2007 metaanalysis on innovativeness effects, Szymanski and colleagues have asked for more rather than less complicated models of innovativeness and to identify and include potentially relevant mediators of the innovativeness-performance relationship, such as specific marketplace factors (Szymanski et al. 2007). This study addresses this gap in research and is the first to analyse the impact of manufacturer innovativeness on the manufacturer's relationship with key market players, i.e., a manufacturer's relationship with its retailers. The results show that retailer dependency mediates the effect of innovativeness on performance. Our findings, therefore, contribute to the literature by providing a new mechanism and an explanation by which innovativeness affects performance.

\section{Managerial Implications}

The results of this study provide the following recommendations to managers. Obviously, managers need to strengthen the firm's innovative capacity to enhance the performance of their companies. By developing the capability to develop radical innovations, manufacturers are able to enhance their performance not only directly but also indirectly by strengthening the manufacturer's position with regard to retailers. This study underscores the relevance of innovativeness for strengthening the manufacturer's position in its relationship with retailers that even avoids problems with aggressive store brands and constrained listing conditions. The development of radically new products is an important means of increasing retailer dependency.

We do not imply that innovation should become a factor of power for manufacturers against the retail channel. We believe that quite the reverse could be established and recommend manufacturers to take measures regarding how both manufacturers and retailers can benefit 
from high innovativeness on the manufacturer side and that do not disadvantage neither the manufacturer nor the retailer.

\section{Limitations and Future Research Directions}

This study has some limitations that, at the same time, opens promising directions for further research. Although the study controls for common method bias, future research can improve the survey method by adding data from retailers that capture their perception of the manufacturer's radical innovation activities as well as the manufacturer-retailer relationship. Potential single informant bias might be mitigated by the fact that the informants were well qualified to report on the variables in the study. Additional data from different informants (manufacturer, retailer, and end consumers) would contribute to the validity of the results. Although our model took control variables with regard to manufacturer size, industry sectors and dynamics, and satisfaction with the relationship into account, some caution is advisable in generalizing the study’s results. Future studies with regard to manufacturer-retailer relationships should also control for firm age, the presence of the manufacturer in the marketplace, and retailer size in relation to manufacturer size. With regard to the convergent reliability of the measurements, the measurement retailer dependency shows an average variance extracted value below the recommended threshold of .5. Further research may consider an improvement or an alternative measurement of this construct.

Although our sample is consistent with the structure of private demand in the different consumer goods areas in Germany and Switzerland (MetroGroup 2012), it is skewed towards large firms. Thus, the sample is not representative of the consumer goods industry in Switzerland and Germany as a whole, Furthermore, future research is encouraged to examine the effect of manufacturer innovativeness on other characteristics of the manufacturer-retailer relationship such as trust and commitment. The authors also suggest the identification of additional mediating factors related to power and dependency structures among market 
players in other relational business settings. To illustrate, in an organizational buying context for industrial goods, innovativeness may influence critical power-related relationship characteristics, such as buyers' idiosyncratic investments in a supplier (Bensaou and Anderson 1999), which, in turn, can affect the overall performance of suppliers.

\section{References}

Ailawadi, K.L. (2001). The retail power-performance conundrum: What have we learned?. Journal of Retailing 77(3): 299-218.

Ailawadi, K.L., N. Borin, and P.W. Farris (1995). Market power and performance: A crossindustry analysis of Manufacturers and Retailers. Journal of Retailing, 71(3): 211-248.

Ailawadi, K.L. and B. Harlam (2004). An empirical analysis of the determinants of retail margins: the role of store-brand share. Journal of Marketing 68(1): 147-165.

Amrouche, N. and G. Zaccour (2006). Shelf space allocation of national and private brands. European Journal of Operations Research 180(2): 648-663.

Anderson, J. C. and J. A. Narus (1990). A model of distributor firm and manufacturer firm working partnerships. Journal of Marketing 54(1): 42-58.

Armstrong, J.S. and T.S. Overton (1977). Estimating nonresponse bias in mail surveys. Journal of Marketing Research 14(3): 396-402.Bagozzi, R.P. and Y. Yi (1988). On the evaluation of structural equation models. Journal of the Academy of Marketing Science 16(1): 74-94.

Bensaou, M. and E. Anderson (1999). Buyer-supplier relations in industrial markets: when do buyers risk making idiosyncratic investments?. Organization Science 10(4): 460-481.

Blois, K. (2010). The legitimacy of power in business-to-business relationships. Marketing Theory 10(2): 161-172.

Bloom, P., G. T. Gundlach, and J. P. Cannon (2000). Slotting allowances and fees: schools of thought and the views of practicing managers. Journal of Marketing 64: 92-108. 
Bloom, P. and V. G. Perry (2001). Retailer power and supplier welfare: The case of WalMart. Journal of Retailing 77: 379-396.Brauer, M. and Borhis, R. Y. (2006). Social Power. European Journal of Social Psychology 36: 601-616.

Brown, J. R., R. F. Lusch, and D. D. Muehling (1983). Conflict and power-dependence relations in retailer-supplier channels. Journal of Retailing 59(4): 53-80.

Burt, S. (2000). The strategic role of retail brands in British grocery retailing. European Journal of Marketing 34(8): 875 - 890.

Calantone, R. J., S. T. Cavusgil, and Z. Yushan (2002). Learning Orientation, Firm Innovation Capability, and Firm Performance. Industrial Marketing Management 31: 515-524.

Chandy, R. K. and G. J. Tellis (1998). Organizing for radical product innovation: the overlooked role of willingness to cannibalize. Journal of Marketing Research 35(4): 474-487.

Chintagunta, P. K., A. Bonfrer, and I. Song (2002). Investigating the effects of store-brand introduction on retailer demand and pricing behavior. Management Science 48(10): 1242-1267.

Chung, H. (2008). Essays on store brand management: The case of vertically differentiated product categories. Syracuse University, School of Management.

Churchill, G. (1979). A paradigm for developing better measures for marketing contrasts. Journal of Marketing Research 16: 64-73.

Collins, A. (2002). The determinants of retailers' margin related bargaining power: evidence from the Irish food manufacturing industry. International Review of Retail, Distribution \& Consumer Research 12(2): 165-189.

Collins, A. and S. Burt (2003). Market sanctions, monitoring and vertical coordination within retailer-manufacturer relationships: the case of retail brand Suppliers. European Journal of Marketing 37(5): 668-689. 
Copeland, J. T. (1994). Prophecies of power: motivational implications of social power for behavioral confirmation. Journal of Personality \& Social Psychology 67(2): 264-277.

Corstjens, J. and M. Corstjens (2000). Store Wars: The Battle for Mindspace and Shelfspace, Wiley, Chichester.

Covin, J. G. and D. P. Slevin (1989). Strategic management of small firms in hostile and benign environments. Strategic Management Journal 10(1): 75-87.

Danneels, E. (2002). The dynamics of product innovation and firm competences. Strategic Management Journal, 23(12): 1095-1121.

Davies, K., C. Gilligan, and C. Sutton (1985). Structural change in grocery retailing: the implications for competition. International Journal of Physical Distribution \& Materials Management 15(2): 3-45.

Davis, G. F. and J. A. Cobb (2010). Resource dependence theory: Past and future. In: Schoonhoven, C. B. and F. Dobbin (eds.). Stanford's Organization Theory Renaissance, 1970-2000 (Research in the Sociology of Organizations 28), Emerald Group Publishing Limited: 21-42.

DeSarbo, W. S., C. A. Di Benedetto, M. Song, and I. Sinha (2005). Revisiting the Miles and Snow strategic framework: uncovering interrelationships between strategic types, capabilities, environmental uncertainty, and firm performance. Strategic Management Journal 26(1): 47-74.

Dobson, P. and M. Waterson (1999). Retailer power: recent developments and policy implications. Economic Policy 28: 135-164.

Doise, W. (1986). Levels of Explanation in Social Psychology. Cambridge: Cambridge University Press.

Draganska, M., D. Klapper, and S. B. Villas-Boas (2010). A larger slice or a larger pie? an empirical investigation of bargaining power in the distribution channel. Marketing Science 29(1): 57-74. 
El-Ansary, A. I. and L. W. Stern (1972). Power measurement in the distribution channel. Journal of Marketing Research 9(1): 47-52.

Emerson, R. M. (1962). Power-dependence relations. American Sociological Review 27(1): $31-41$.

Feldman, J. M. and J. G. Lynch (1988). Self-generated validity and other effects of measurement on belief, attitude, intention and behavior. Journal of Applied Psychology 73(3): 421-435.

Fornell, C. and D. F. Larcker (1981). Evaluating structural equation models with unobservable variables and measurement error. Journal of Marketing Research, 18(1): 39-50.

Frazier, G. L. (1999). Organizing and managing channels of distribution. Journal of the Academy of Marketing Science 27(2): 226-240.

Galinsky, A. D., D. H. Gruenfeld, and J. C. Magee (2003). From power to action. Journal of Personality and Social Psychology 85: 453-466.

Garcia-Morales, V. J., F. J. Llorens-Montes, and A. J. Verdi-Jover (2006). Antecedents and consequences of organizational innovation and organizational learning in entrepreneurship. Industrial Management \& Data Systems 106(1): 21-42.

Gaski, J. F. (1984). The theory of power and conflict in channels of distribution. Journal of Marketing 48(3): 9-29.

Gaski, J. F. and J. R. Nevin (1985). The differential effects of exercised and unexercised power sources in a marketing channel. Journal of Marketing Research 22(2): 130-142.

Geylani, T., A. J. Dukes, and K. Srinivasan (2007). Strategic manufacturer response to a dominant retailer. Marketing Science 26(2): 164-178.

Giebels, E., C. K. W. De Dreu, and E. Van de Vliert (2000). Interdependence in negotiation: Effects of exit options and social motive on distributive and integrative negotiation. European Journal of Social Psychology 30: 255-272. 
Glynn, M. S., J. B. Roderick, and J. Motion (2012). The benefits of manufacturer brands to retailers. European Journal of Marketing 46(9): 1127-1149.

Gomez, M. and N. R. Benito (2008). Manufacturer's characteristics that determine the choice of producing store brands. European Journal of Marketing 42(1/2): 154-177.

Gomez, M. and N. Rubio (2008). Shelf management of store brands: Analysis of manufacturers’ perceptions. International Journal of Retail and Distribution Management 36(1): 50-70.

Grant, R. M. (1987). Manufacturer-retailer relations: the shifting balance of power. In Johnson, G. (ed.) Business Strategy and Retailing, Wiley: 43-58

He, Z. L. and P. K. Wong (2004). Exploration vs. exploitation: an empirical test of the ambidexterity hypothesis. Organization Science 15(4): 481-494.

Hernandez-Espallardo, M. and F.-J. Molina-Castillo (2012). Learning processes, their impact on innovation performance and the moderating role of radicalness. European Journal of Innovation Management 15(1): 77-98.

Hillman, A. J., M. C. Withers, and B. J. Collins (2009). Resource dependence theory: a review. Journal of Management 35(6): 1404-1427.

Hooley, G. J., G. E. Greenley, J. W. Cadogan, and J. Fahy (2005). The performance impact of marketing resources. Journal of Business Research 58(1): 18-27.

Hult, G. T. M., R. F. Hurley, and G. A. Knight (2004). Innovativeness: Its antecedents and impact on business performance. Industrial Marketing Management 33(5): 429-438.

Hurley, R. F. and G. T. M. Hult (1998). Innovation, Market Orientation, and Organizational Learning: An Integration and Empirical Examination. Journal of Marketing 62(3): 4254.

Huxham, C. and N. Beech (2009). Inter-organizational Power. In: Cropper, S., C. Huxham, M. Ebers, and P. Smith Ring (eds.), The Oxford Handbook of Inter-Organizational Relations, Oxford University Press: 1-39. 
Iacobucci, D., N. Saldanha, and X. Deng (2007). A meditation on mediation: evidence that structural equations models perform better than regressions. Journal of Consumer Psychology (Lawrence Erlbaum Associates) 17(2): 139-153.

Jaworski, B. J. and A. K. Kohli (1993). Market orientation: antecedents and consequences. Journal of Marketing. 57(July): 53-70.Kelley, H. H. and J. W. Thibaut (1978). Interpersonal Relationships: A Theory of Interdependence. Wiley: New York.

Keltner, D., D. H. Gruenfeld, and C. Anderson (2003). Power, approach, and inhibition. Psychological Review 110: 265-284.

van Kleef, G. A., C. K. W. de Dreu, D. Pietroni, and A. S. R. Manstead (2006): Power and emotion in negotiation: Power moderates the interpersonal effects of anger and happiness on concession making. European Journal of Social Psychology 36: 557581.

Krishnan, T. V. and H. Soni (1997). Guaranteed profit margins: A demonstration of retailer power. International Journal of Research in Marketing 14(1): 35-56.

Kumar, N. and J.-B. E. M. Steenkamp (2007a). Private Label Strategy. How to Meet the Store Brand Challenge. Harvard Business School Press, Boston.

Kumar, N. (2007b). Brand versus brand. International Commerce Review 7(1): 46-53.

Lan, L., P. K. Kannan, and B. T. Ratchford (2007). New product development under channel acceptance. Marketing Science 26(2): 149-163.

Lindell, M. K. and D. J. Whitney (2001). Accounting for common method variance in crosssectional research designs. Journal of Applied Psychology 86(1): 114-121.

Lumpkin, G. T. and G. G. Dess (1996). Clarifying the entrepreneurial orientation construct and linking it to performance. Academy of Management Review 21(1): 135-172.

Martín-Herrán, G., S. Taboubi, and G. Zaccour (2006). The impact of manufacturers' wholesale prices on a retailer's shelf-space and pricing decisions. Decision Sciences 37(1): 71-90. 
Marx, L. and G. Shaffer (2004). Opportunism in multilateral vertical contracting: nondiscrimination, exclusivity, and uniformity: Comment. The American Economic Review 94(3): 796-801.

Messinger, P. R. and C. Narasimhan (1995). Has power shifted in the grocery channel?. Marketing Science 14(2): 189-223.

MetroGroup (2012). Metro-Handelslexikon 2011/2012. MetroGroup, Duesseldorf.

Morris, D. (1979). The strategy of own brands. European Journal of Marketing 13(2): 59 78.

Mysen, T., G. Svensson, and N. Högevold (2012). Relationship Quality—Relationship Value and Power Balance in Business Relationships: Descriptives and Propositions. Journal of Business-to-Business Marketing 19: 248-285.

Narasimhan, C. and R. T. Wilcox (1998). Private labels and the channel relationship: a crosscategory analysis. Journal of Business 71(4): 573-600.

Pfeffer, J. and G. R. Salancik (1978). The external control of organizations: A resource dependence perspective. New York: Harper \& Row.

Podsakoff, P. M. and D. W. Organ (1986). Self-reports in organizational research: problems and prospects. Journal of Management 12(4): 531-544.

Scott Morton, F. and F. Zettelmeyer (2004). The Strategic Positioning of Store Brands in Retailer-Manufacturer Negotiations. Review of Industrial Organization 24(2): 161194.

Song, M. and Y. Zhao (2004). A neural network for predicting manufacturers' perceived cooperation with distributors in the new product development process. Journal of Business-to-Business Marketing 11(3): 53-78.

Sorescu, A. B. and J. Spanjol (2008). Innovation's effect on firm value and risk: insights from consumer packaged goods. Journal of Marketing 72(2): 114-132. 
Spanos, Y. E. and G. P. Prastacos (2004). The effects of environment, structure, and dynamic capabilities on product innovation strategy. International Journal of Entrepreneurship \& Innovation Management 4(6): 620-638.

Sriram, S. and V. Kadiyali (2009). Empirical investigation of channel reactions to brand introductions. International Journal of Research in Marketing 26(4): 345-355.

Steenkamp, J.-B. E. M., M. C. Dekimpe (1997). The increasing power of store brands: building loyalty and market share. Long Range Planning 30(6): 917-930.

Suarez, M. G. (2005). Shelf space assigned to store and national brands. International Journal of Retail \& Distribution Management 33(11): 858-878.

Swan, P. L. (1970). Market structure and technological progress: the influence of monopoly on product innovation. Quarterly Journal of Economics 84(4): 627-638.

Szymanski, D. M., M. W. Kroff, and L. C. Troy (2007). Innovativeness and new product success: insights from the cumulative evidence. Journal of the Academy of Marketing Science 35(1): 35-52.

Udell, G. G. and L. S. Pettijohn (1991). A retailer's view of industrial innovation: An interview with David Glass, President and CEO of Wal-Mart Stores Inc.. Journal of Product Innovation Management 8(4): 231-239.

Urban, G. L., T. Carter, S. Gaskin, and Z. Mucha (1986). Market share rewards to pioneerin brands: an empirical analysis and strategic implications. Management Science 32(6): 645-359.

Thibaut, J. W. and H. H. Kelley (1959). The Social Psychology of Groups, Wiley: New Yorkvan Everdingen, Y. M., L. M. Sloot, E. van Nierop, and P. C. Verhoef (2011). Towards a Further Understanding of the Antecedents of Retailer New Product Adoption. Journal of retailing 87(4): 579-597. 
Verhoef, P.-C., E. J. Nijssen, and L. M. Sloot (2000). Strategic reactions of national brand manufacturers towards private labels: An empirical study in The Netherlands. European Journal of Marketing 36(11/12): 1309-1326.

Weber, S.A. and S. M. Anders (2007). Price rigidity and market power in German retailing. Managerial \& Decision Economics 28(7): 737-749.

Williams, L. J., J. R. Edwards, and R. J. Vandenberg (2003). Recent advances in causal modeling methods for organizational and management research. Journal of Management 29(6): 903 -936.

Yu, J. P. and D. T. Pysarchik (2002). Economic and non-economic factors of Korean manufacturer-retailer relations. International Review of Retail, Distribution and Consumer Research 12(3): 297-318. 
Table 1

Construct measurement

\begin{tabular}{|c|c|c|c|c|c|c|}
\hline Construct & Mean & $\begin{array}{l}\text { Standard } \\
\text { Deviation }\end{array}$ & SFL & t-value & $\begin{array}{c}\text { Cronbach's } \\
\text { Alpha }\end{array}$ & $\begin{array}{l}\text { Factor } \\
\text { reliability }\end{array}$ \\
\hline Manufacturer innovativeness & 3.68 & 0.91 & & & $0.72^{\wedge}$ & 0.72 \\
\hline Compared to our competitors we develop many radically new products.* & 3.61 & 1.05 & 0.71 & 7.84 & & \\
\hline $\begin{array}{l}\text { The expenses for Research \& Development relating to radically new products } \\
\text { have increased within the last years.* }\end{array}$ & 3.75 & 1.01 & 0.82 & 8.70 & & \\
\hline Retailer dependency & 2.66 & 0.92 & & & 0.68 & 0.69 \\
\hline $\begin{array}{l}\text { If we discontinued supplying to the retailers, they would have difficulty making } \\
\text { up the sales volume in our product category. }{ }^{*}\end{array}$ & 2.91 & 1.27 & 0.67 & 9.91 & & \\
\hline $\begin{array}{l}\text { If we were to stop doing business with the retailers, they would find it hard to } \\
\text { source products quickly with similar customer appeal.* }\end{array}$ & 2.86 & 1.22 & 0.64 & 9.26 & & \\
\hline $\begin{array}{l}\text { If our product is out of stock, their customers are unlikely to purchase a } \\
\text { substitute.* }^{*}\end{array}$ & 2.25 & 1.02 & 0.63 & 9.84 & & \\
\hline Store brand aggressiveness & 3.21 & 0.93 & & & 0.85 & 0.85 \\
\hline Our retailers quickly develop their store brand.* & 3.25 & 1.11 & 0.68 & 13.10 & & \\
\hline Store brands are an increasing threat on our products. ${ }^{*}$ & 3.21 & 1.10 & 0.75 & 15.46 & & \\
\hline $\begin{array}{l}\text { Promising product innovations are quickly followed by me-too products of } \\
\text { retailers.* }\end{array}$ & 3.37 & 1.05 & 0.86 & 17.99 & & \\
\hline Our retailers have an store brand alternative for almost all products.* & 3.01 & 1.22 & 0.76 & 16.63 & & \\
\hline Listing constraints & 3.94 & 0.73 & & & 0.70 & 0.74 \\
\hline $\begin{array}{l}\text { Our retailers expect new products to establish on the market more } \\
\text { quickly.* }\end{array}$ & 4.03 & 0.77 & 0.70 & 9.50 & & \\
\hline A product is given less and less time to prevail in the shelves.* & 4.09 & 0.84 & 0.85 & 13.76 & & \\
\hline The listing fees have increased within the last years.* & 3.71 & 1.13 & 0.52 & 8.88 & & \\
\hline Manufacturer overall performance & 3.46 & 0.76 & & & 0.88 & 0.88 \\
\hline Overall profit compared to the main competitor ${ }^{\star \star}$ & 3.40 & 0.80 & 0.74 & 13.55 & & \\
\hline Return on Investment compared to the main competitor** & 3.41 & 0.80 & 0.81 & 16.40 & & \\
\hline Overall profit goal ${ }^{\star \star \star}$ & 3.54 & 1.02 & 0.77 & 15.96 & & \\
\hline Return on Investment goal ${ }^{\star \star \star}$ & 3.47 & 0.89 & 0.90 & 19.03 & & \\
\hline \multicolumn{7}{|l|}{ Control Variables } \\
\hline Manufacturer Firm Size & 4.84 & 1.81 & & & & \\
\hline Number of full-time employee (In) & 961.73 & 5498.12 & 1.00 & 24.18 & & \\
\hline Industry uncertainty and turbulence & 2.66 & 0.56 & & & 0.65 & 0.65 \\
\hline In our industry, customers' preferences change quite a bit over time. & 3.10 & 1.07 & 0.56 & 8.70 & & \\
\hline In our industry, consumers tend to look for new products all the time. & 3.49 & 1.04 & 0.69 & 9.85 & & \\
\hline In our industry, new products and services enter the market faster and faster. & 3.84 & 0.95 & 0.60 & 9.39 & & \\
\hline Manufacturer non-economic satisfaction with retailers & 3.35 & 0.76 & & & 0.93 & 0.93 \\
\hline In general, we are happy with our business relationships with the retailers. & 3.60 & 0.85 & 0.89 & 18.12 & & \\
\hline In general, we consider our retailers to be good co-operation partners for us. & 3.51 & 0.88 & 0.93 & 21.52 & & \\
\hline The relationships between the retailers and us are very positive. & 3.62 & 0.89 & 0.88 & 18.68 & & \\
\hline \multicolumn{7}{|l|}{ Industry } \\
\hline 1. food and beverages & 0.36 & 0.48 & & & & \\
\hline 2. textiles, clothes, and footwear & 0.16 & 0.36 & & & & \\
\hline 3. cleaning, hygiene, and cosmetics, & 0.06 & 0.23 & & & & \\
\hline 4. office supplies, computer, and telecommunications & 0.07 & 0.25 & & & & \\
\hline 5. do-it-yourself and building material & 0.03 & 0.16 & & & & \\
\hline 6. leisure, sports, and activities & 0.06 & 0.25 & & & & \\
\hline 7. electric appliances and lighting & 0.10 & 0.30 & & & & \\
\hline 8. consumer electronics, audio media, and audio-visual media & 0.02 & 0.13 & & & & \\
\hline 9. household goods, glassware, and dishware & 0.03 & 0.18 & & & & \\
\hline 10. furnishings & 0.05 & 0.22 & & & & \\
\hline 11. personal goods and services & 0.03 & 0.17 & & & & \\
\hline 12. others & 0.04 & 0.20 & & & & \\
\hline
\end{tabular}

*five-point scale: 1='strongly disagree'; 5='strongly agree'

**five-point scale: 1='much worse'; $5=$ 'much better'

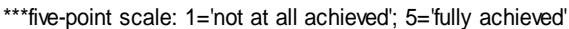

^pearson correlation

$\mathrm{SFL}=$ standardized factor loading 
Table 2

Correlation matrix

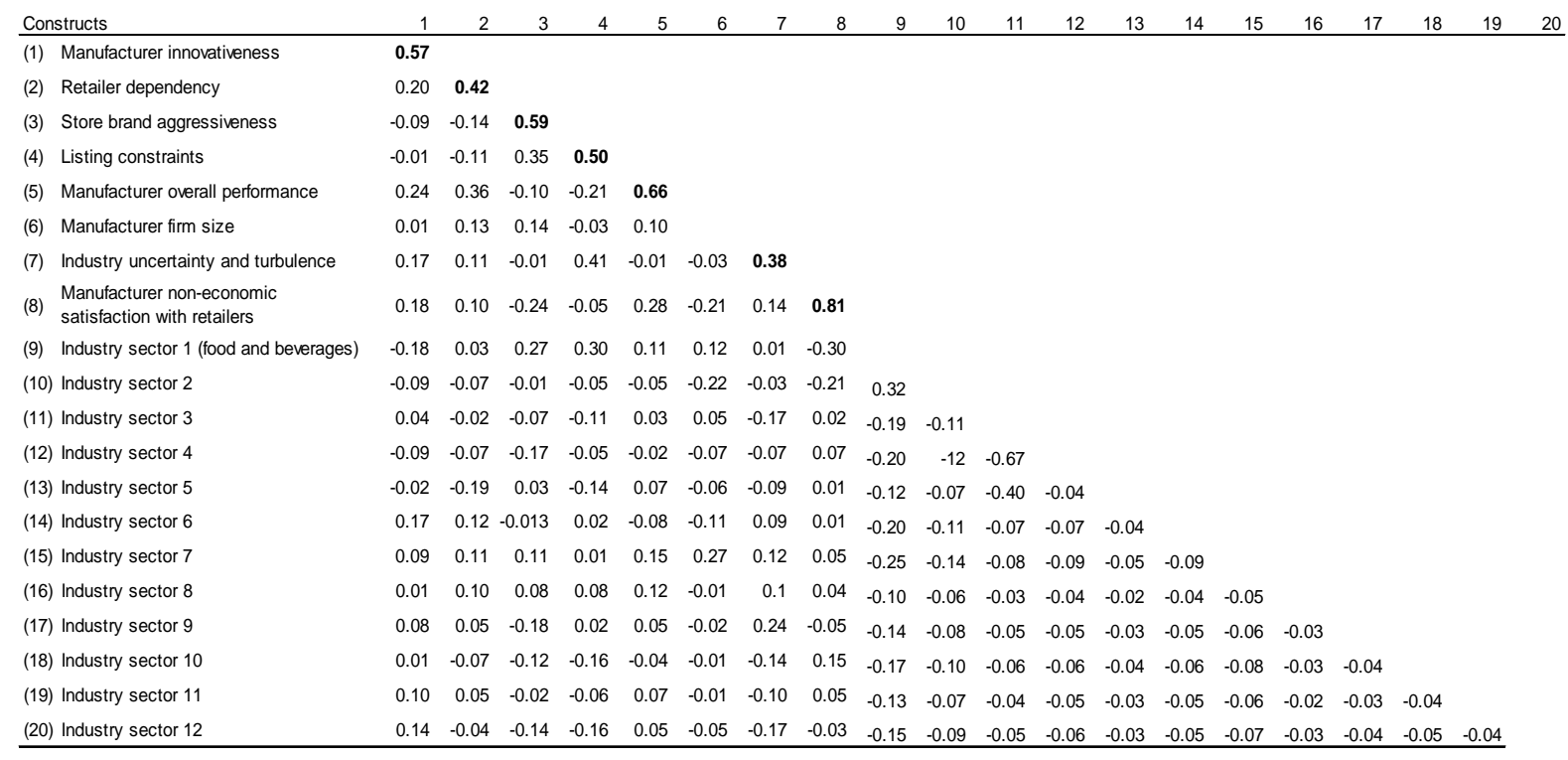

Diagonal elements in bold are average variances extracted for the constructs 
Figure 1

\section{Conceptual model}

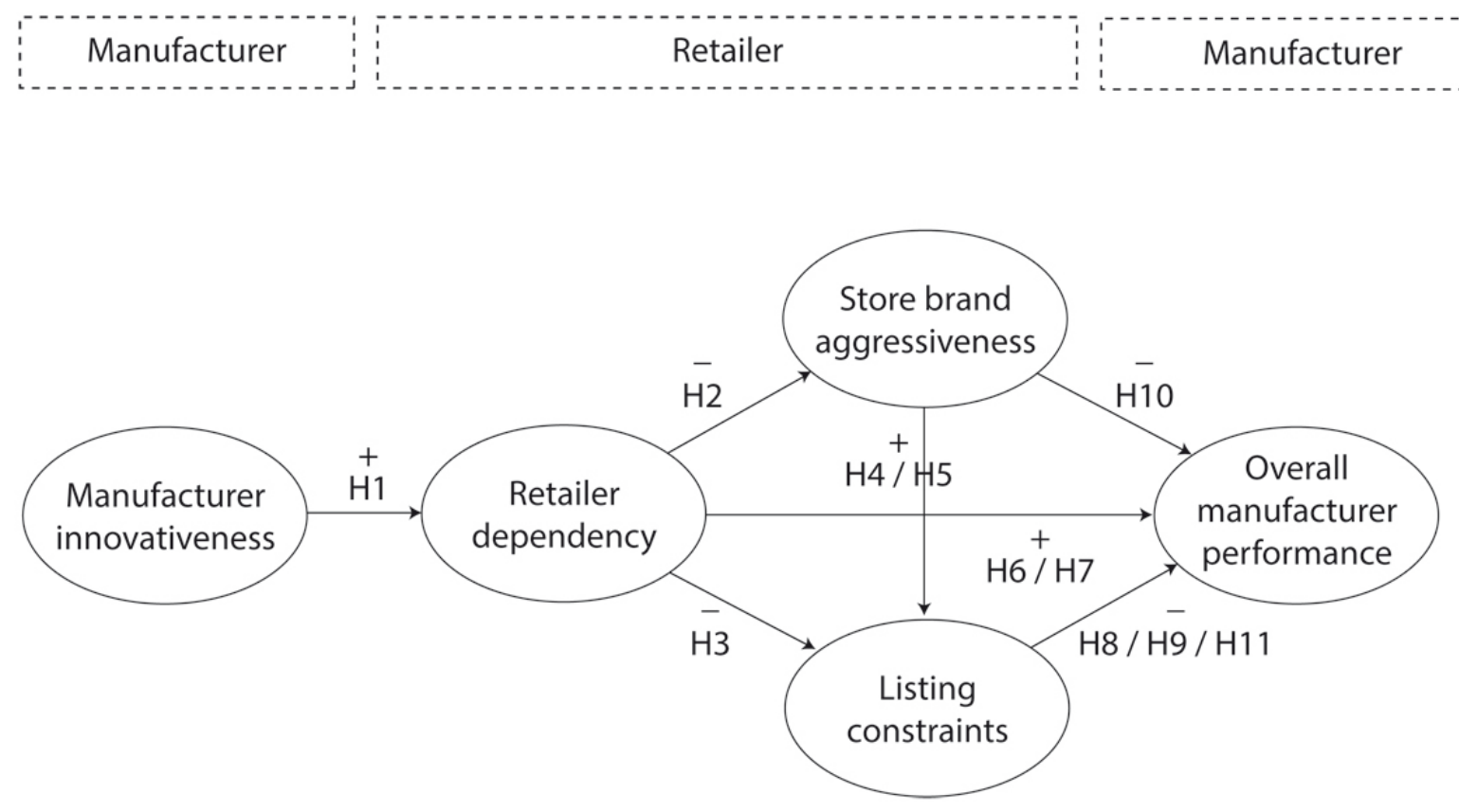

Figure 2

\section{Empirical model}

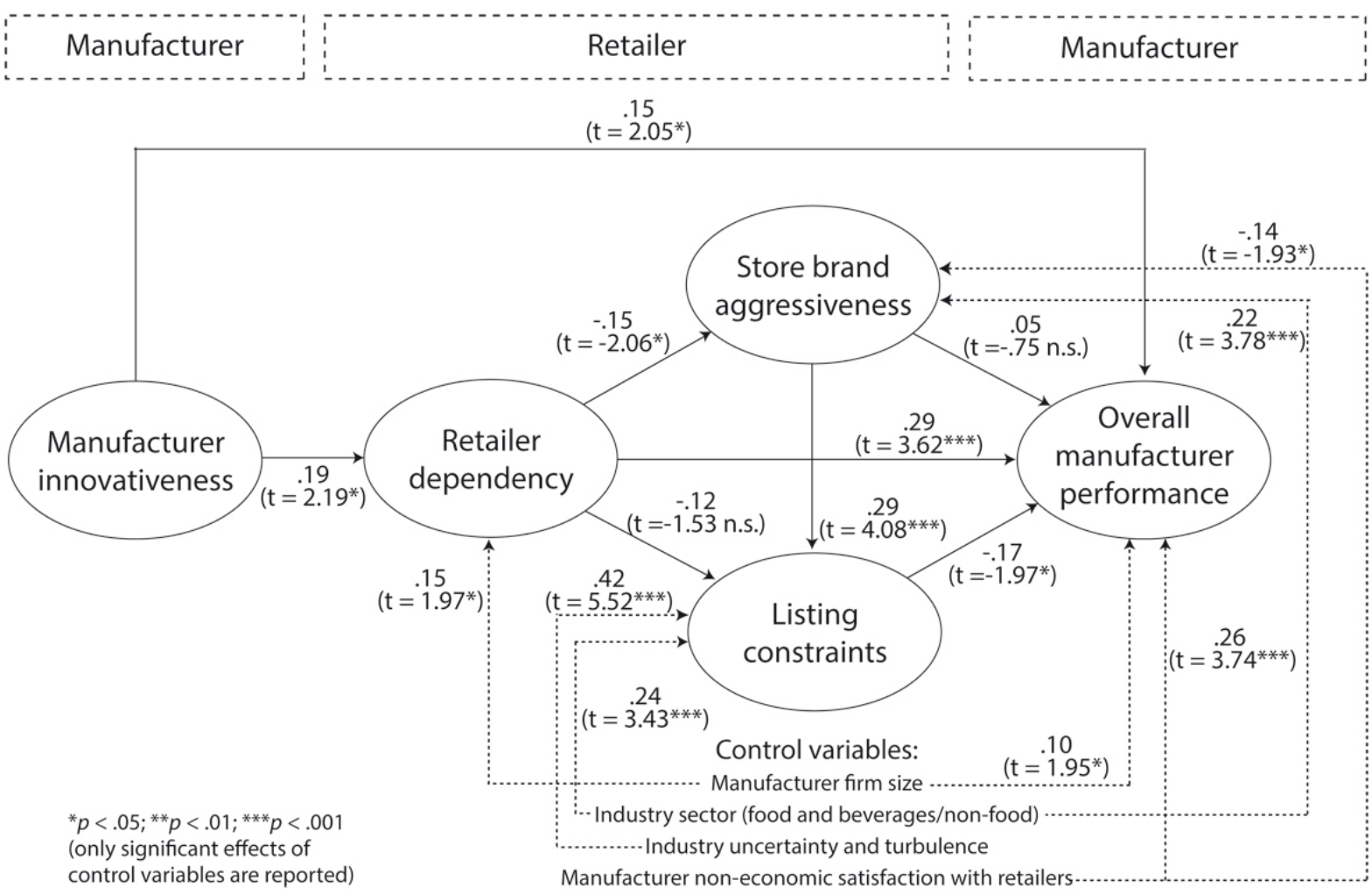




\section{Practitioner’s summary}

Manufacturers are frequently confronted with retailers who exercise their power by pursuing aggressive store brand policies and imposing severe listing constraints. In this article, we investigate manufacturer innovativeness as a managerial lever to shift the power balance between manufacturers and retailers.

The study findings contribute to the literature on channel relationships. With innovativeness, we introduce a managerial lever by which a manufacturer can proactively strengthen its power position towards retailers. The findings further contribute to research on innovativeness by showing that specific characteristics of the manufacturer-retailer relationship serve as factors that mediate the effects of innovativeness on performance.

From a managerial viewpoint, obviously, managers need to strengthen the firm's innovative capacity to enhance the performance of their companies. By developing the capability to develop radical innovations, manufacturers are not only able to enhance their performance directly, but also indirectly by strengthening the manufacturer's position towards retailers. Our study underscores the relevance of innovativeness for strengthening the manufacturer's position in the relationship with retailers that even avoids problems with aggressive store brands and listing constraints. The development of radically new products is an important mean to increase retailer dependency.

We do not imply that innovation should become a factor of power for manufacturers against the retail channel. We believe that quite the reverse could be established and recommend manufacturers to take measures regarding how both manufacturers and retailers can benefit from high innovativeness on the manufacturer side and that do not disadvantage neither the manufacturer nor the retailer. 